\title{
A Cautionary Tale of Two Streetcars: Little Rock's River Rail and Tampa's TECO Line
}

\author{
Luis Enrique Ramos-Santiago and Jeffrey Brown, Ph.D. \\ Florida State University \\ Hilary Nixon, Ph.D. \\ San Jose State University
}

\begin{abstract}
Planners and policymakers in dozens of U.S. cities are considering making streetcar investments in the hope of promoting economic development, encouraging tourism, carrying transit riders, and/or achieving a host of other local objectives. Most observers look to Portland, Oregon, as a model of successful streetcar development, but this paper considers the experiences of two less successful communities, Little Rock, Arkansas, and Tampa, Florida. Using a combination of key informant interviews and local and national transit data, the authors assess the goals of streetcar implementation and the performance of the streetcars in these two cities, seeking to understand the reasons for their performance and identify lessons for other communities.
\end{abstract}

\section{Introduction}

Planners and policymakers in dozens of U.S. cities are considering making streetcar investments in the hope of promoting economic development, encouraging tourism, carrying transit riders, and/or achieving a host of other local objectives. Advocates frequently point to the example of Portland, Oregon, as a model for their own community's streetcar aspirations, because of the Portland streetcar's purported role in promoting hundreds of millions of dollars in economic development near the streetcar line and its relatively high ridership and stronger transportation performance among the modern-era U.S. streetcar systems (Hovee and Gustafson 2012; Ramos et al. 2014). Among modern-era U.S. streetcars, Portland is indeed the standout performer, with the highest ridership and most productive service (Ramos et al. 2014), and its claimed economic development effects are the most widely touted (Golem and Smith-Heimer 2012). However, the authors suggest that planners and policymakers in cities that are considering building their own streetcar 
line might actually learn more useful lessons from the experiences of the less successful streetcar cases than from Portland's experience.

This paper examines the cautionary experiences of two streetcar cities: Little Rock, Arkansas and Tampa, Florida. In both cities, planners and policymakers implemented streetcars to promote economic development and encourage tourism in their respective communities. The streetcars' potential roles as transit services were secondary considerations in local decisionmaking (Brown et al. 2014). However, the experiences of both Little Rock's River Rail and Tampa's TECO Line streetcar have not lived up to their proponents' original expectations. The economic development and tourism promotion results are questionable, and the ridership results are poor and worsening over time. The authors examine the experiences of these two less successful streetcar cities using a combination of insights gained from key informant interviews and transit data obtained from local agencies and national data sources. The objective was to better understand how these two less successful modern-era streetcars are doing and, more importantly, why, as well as to derive lessons from their experiences that might be of use to other cities that are considering making streetcar investments.

\section{Basic Characteristics of the River Rail and TECO Line Streetcars}

The two streetcar systems of interest are Little Rock's River Rail streetcar, consisting of two lines (Blue, Green) operated by the Central Arkansas Transit Authority (CATA), and Tampa's TECO Line streetcar, a single-line service operated by Hillsborough Area Regional Transit (HART) (Tampa Electric Company [TECO] purchased naming rights for the line). Photos of streetcars in the two cities are shown in Figures 1 and 2.

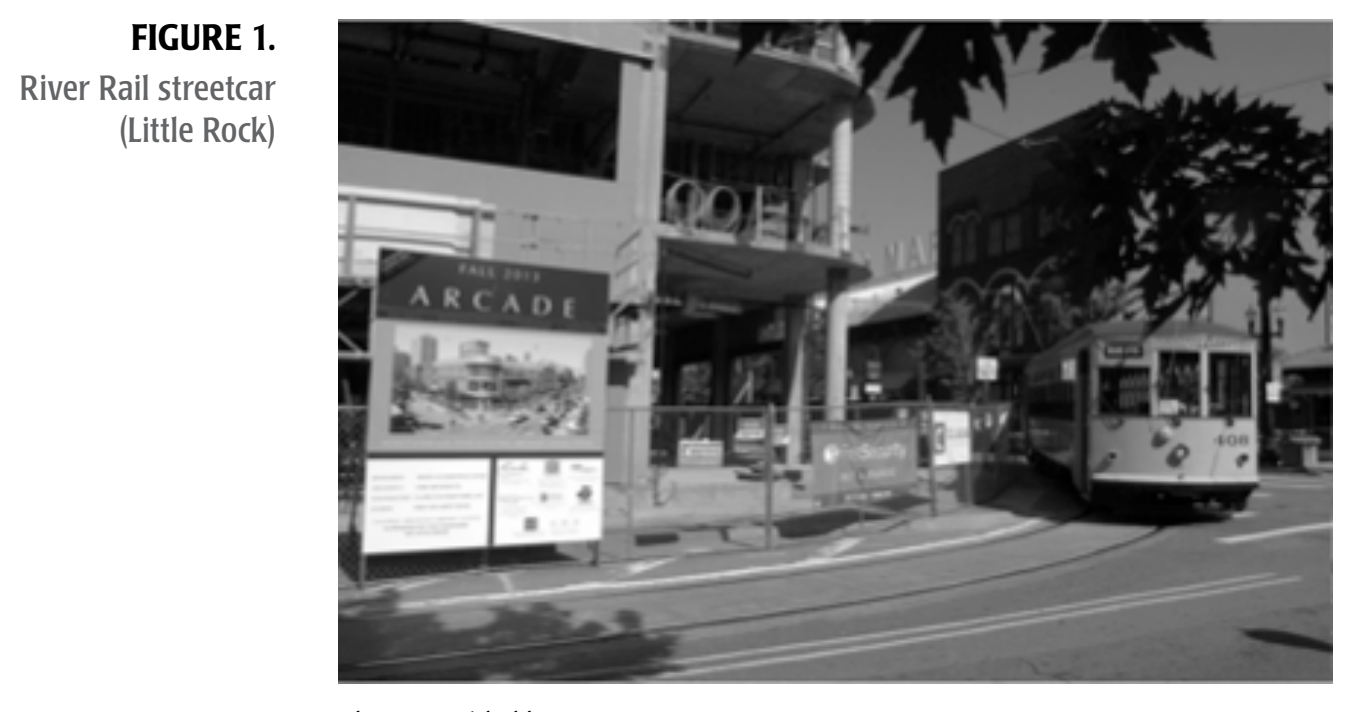

Photo provided by CATA 
FIGURE 2.

TECO Line streetcar (Tampa)

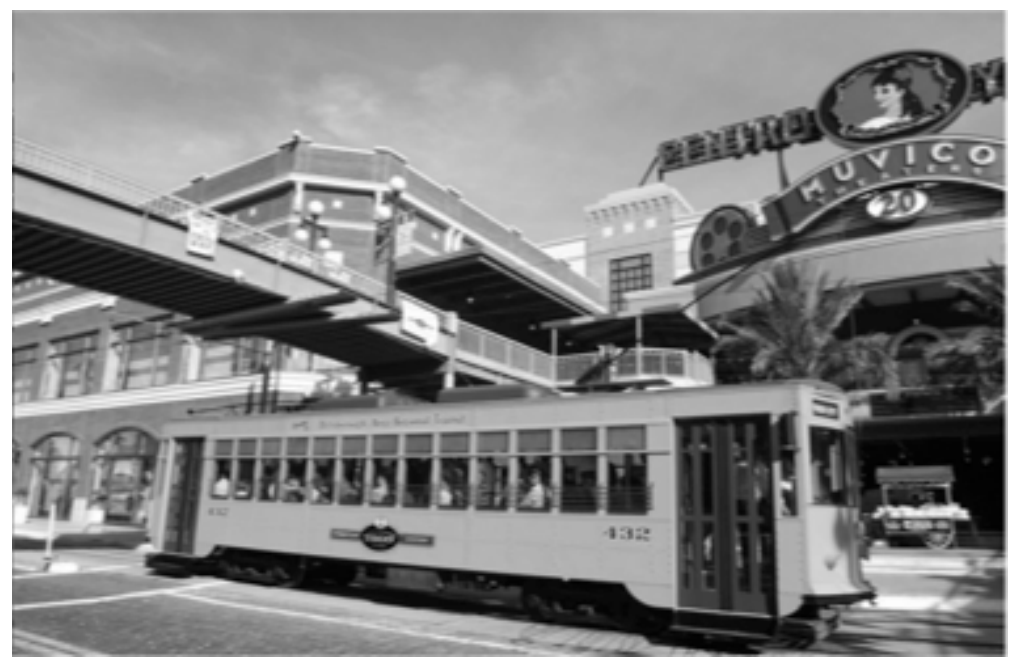

Photo provided by HART

River Rail streetcars operate on a 3.4-mile alignment that serves 15 stops in the downtowns of Little Rock and North Little Rock. The streetcar system cost $\$ 28.8$ million to build, and the streetcars operate in mixed traffic, except for a 0.4-mile dedicated segment on a bridge over the Arkansas River that connects the two downtowns. The first River Rail line opened in the latter part of 2004, with a new extension opening in 2007.

The River Rail streetcar line was built principally to serve visitors and promote economic development in the downtowns of Little Rock and North Little Rock (Brown et al. 2014). River Rail functions as a short circulator system within and between the two downtowns (see Figure 3). Service operates on consistent 25-minute headways throughout the day, and service hours start after the morning rush hour on weekday mornings to avoid conflicts between streetcar vehicles and automobile commuter traffic. The streetcar fare is $\$ 1$ per ride; travelers can transfer free from CATA buses to River Rail, but streetcar riders must pay an additional fare to ride a CATA bus. 
FIGURE 3.

Map of River Rail alignment

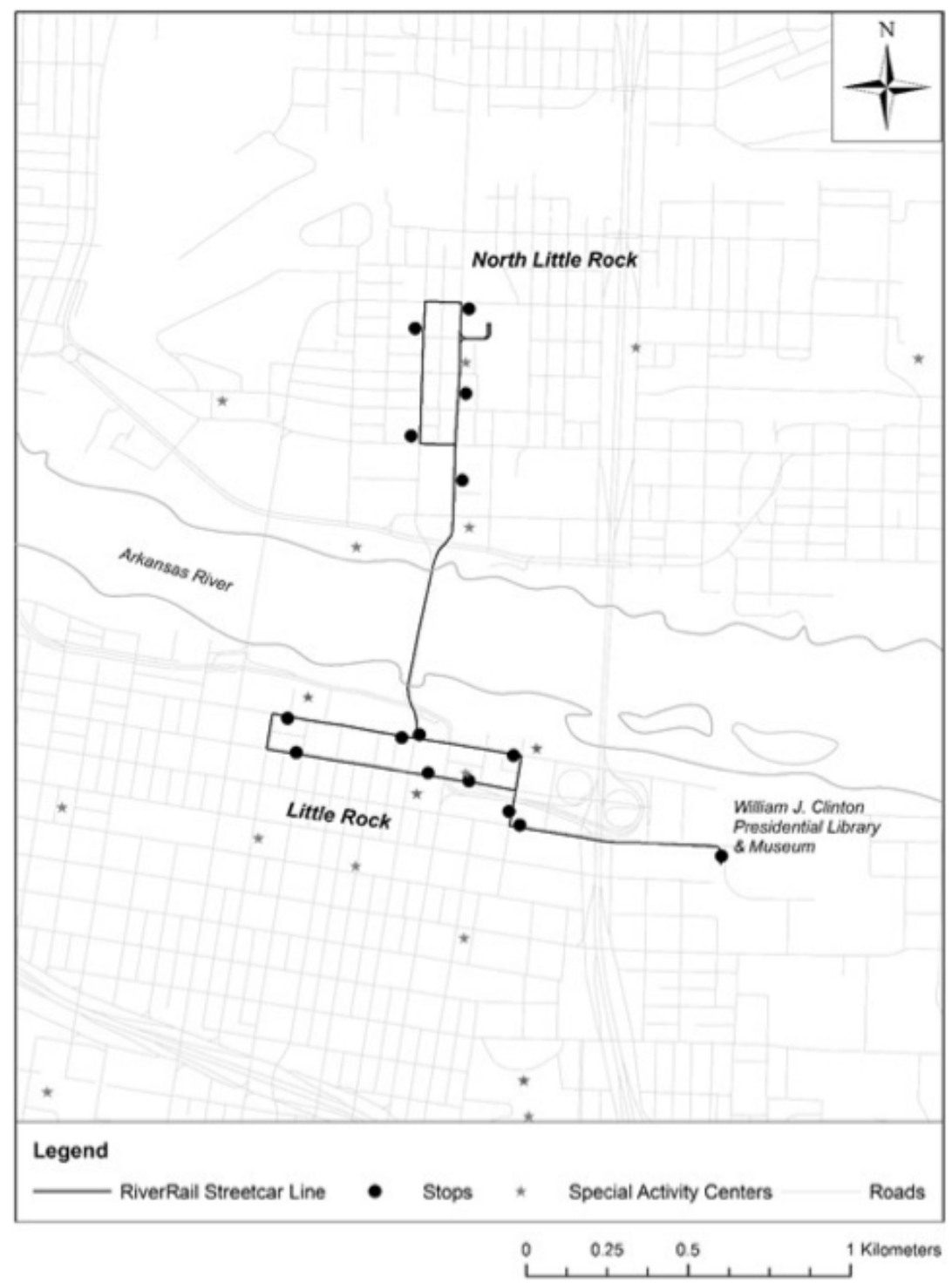

Source: Central Arkansas Transit Authority (CATA), "GIS Shapefiles for CATA bus routes, River Rail streetcar line, and River Rail streetcar stops," provided by Central Arkansas Transit Authority staff, May 2014.

TECO Line streetcars operate on a 2.7-mile exclusive alignment (Figure 4) that cost $\$ 60+$ million to build, including a rail facility and vehicles (personal communication, HART Board member, September 2014); the line serves 11 stops in areas east and south of downtown Tampa and links the nearby Ybor City tourism/historic district to the still-underdeveloped Channelside district. The TECO Line opened in the latter part of 2002 and originated as the proposed "first leg" of a larger light rail transit (LRT) system, but it soon evolved into a redevelopment and tourism-focused service of much shorter length (Brown et al. 2014). However, there were no system plans, no formal long-range plans, nor any designs prepared for future extensions for this particular vision of the streetcar (personal communication, HART Board member, 2014). 
FIGURE 4.

Map of TECO Line alignment

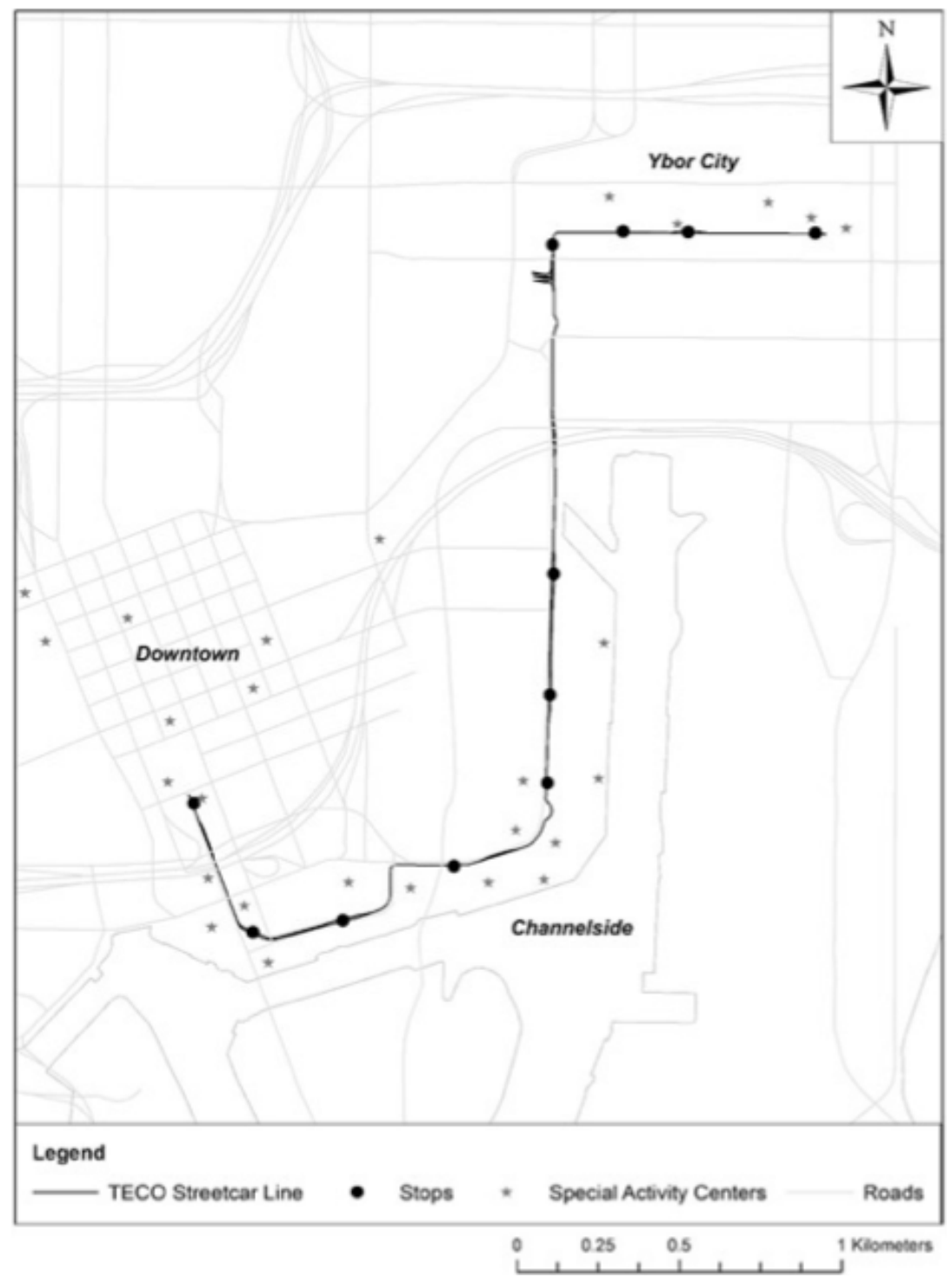

Source: Hillsborough Area Regional Transit (HART), "Transit Network Shapefiles (2012)," http://www.gohart.org/about/data_download/data_download.html (accessed October 2, 2012)

Although regional and transit planners reported that significant real estate investments, estimated by some observers to total nearly $\$ 1$ billion, had been made near the streetcar alignment, the line still serves what most interviewees characterized as a largely underdeveloped waterfront district (Channelside) located between the entertainment/ tourist-oriented Ybor City area and Tampa's Convention Center (see Figure 4). Between these major destinations are several activity centers oriented towards serving tourists and visitors, including hotels, cruise terminals, an aquarium, a waterfront shopping mall, and a sports arena. Streetcar service operates on consistent 20-minute headways on weekdays and 30-minute headways on weekends starting at 12:00 noon Sunday through Thursday and at 11:00 AM Friday and Saturday. The fare is $\$ 2.50$ per ride, and streetcar riders can transfer to HART buses without paying an additional fare. 


\section{Research Objectives, Methodology and Data Sources}

The research objective of this study was to better understand how the streetcars in the two cities are performing and to identify possible explanations for their performance. It became clear during the early phases of the research that economic development, tourism promotion, and other non-transportation objectives were the most important objectives for streetcar development in these two cities, so the authors decided to investigate these issues. The authors were struck by the fact that few formal assessments of the performance of the streetcar systems with respect to these issues had been conducted in either city. The sole exception was an economic development study conducted by Little Rock's CATA that used geographic information systems (GIS) analysis to estimate a total of about $\$ 1$ billion in development activity within close proximity of the streetcar alignment (Central Arkansas Transit Authority 2012). However, the study did not attempt to control for other factors that might explain the level of development activity. There were no similar studies available for Tampa.

The lack of such formal assessments of non-transportation streetcar performance led the authors to rely on key informant interviews for this part of the investigation; these one-hour semi-structured telephone interviews are discussed below. The transportation performance assessment relied on ridership, productivity, and other performance data for a period extending from 2005, the first full year that both streetcars were in operation, to 2012, the most recent year for which data were available from the National Transit Database (accessed via Florida Department of Transportation [FDOT] 2013). The sections that follow discuss the non-transportation performance of the streetcars and their transportation performance.

\section{Interviews about Streetcar Non-Transportation Goals}

The authors conducted one hour semi-structured telephone interviews with key informants in both cities to better understand the goals and objectives of streetcar implementation and their assessment of the streetcar's performance in meeting these objectives. These interviews proved particularly useful in understanding the non-transportation roles the streetcars were intended to play, which proved to be the critical factors driving local decisionmaking around the streetcars in both cities. The authors selected the interviewees to represent a diverse set of key local actors, including transit planners, regional planners, developers, business leaders, and streetcar advocates; the specific individuals were identified through a snowball process in which interviewees were asked to identify other potential candidates for interview. Most had been involved in streetcar issues for several years in their community. The authors conducted three interviews for Little Rock and seven interviews for Tampa (see Table 1); there were fewer interviews in Little Rock due to the difficulty in identifying informants who were willing to be interviewed. The informants are identified in Table 1 by role to maintain their anonymity. The authors first considered the interviewees' identification of streetcar goals and then their assessment of goal attainment, for each city in turn. 
TABLE 1.

Key Informants for Streetcar Interviews

\begin{tabular}{|l|l|}
\hline \multicolumn{1}{|c|}{ Little Rock } & \multicolumn{1}{c|}{ Tampa } \\
\hline Transit Planner & Regional Planner \\
\hline Regional Planner & Transit Planner \\
\hline Tourism and Visitors Expert & Streetcar Marketing Specialist \\
\hline & Economic Development Specialist \\
\hline & Business Community 1 \\
\hline & Business Community 2 \\
\hline & Chamber of Commerce Representative \\
\hline
\end{tabular}

\section{Streetcar Non-Transportation Goals in Little Rock}

The interviewees identified two sets of goals for streetcar implementation in Little Rock. The first goal was to promote downtown development; the second was to promote tourism and visitorship.

The regional planner interviewed recalled River Rail's emergence as part of a downtown development strategy articulated in a study undertaken by local business leaders and developers in partnership with the Urban Land Institute; the mayors of Little Rock and North Little Rock were engaged in this effort as well. Participants viewed the streetcar as a potential "catalyst" for development. It was observed that the streetcar was supported by a "few big players" that included local developers and key elected officials who were interested in downtown revitalization. These key figures were able to secure federal funding earmarks to aid in streetcar construction. Major entities such as the Clinton Presidential Library and Heifer International participated in the second phase of streetcar construction, with the Library designing, building, and maintaining its own stop. The transit planner interviewed thought that former President Clinton's influence helped the community obtain the funding for the second streetcar phase that included extending service to the Clinton Library.

The transit planner noted the primarily tourism and visitor orientation of the streetcar service and stated that the service was tourism-oriented and not transit-oriented. This focus is reflected in policy decisions such as starting service on weekday mornings at 8:20 $\mathrm{AM}$, after much of the morning commute is over, to avoid streetcar conflicts with motor vehicle congestion. The streetcar does not have its own right-of-way and often is hindered by congestion as well as vehicles parked within its right-of-way. It also was noted that streetcar operators serve as tour guides who identify points of interest along the streetcar alignment to streetcar riders, which further indicates the primarily visitor orientation of the service.

The third interviewee, who promotes tourism and convention activity in the community, spoke of the streetcar's role in connecting the two downtowns and enabling people to easily reach the major visitor attractions located there. Tourism promotion figured prominently in his assessment of the streetcar's goals; he noted that the local convention and visitors bureau worked closely with the other agencies involved in streetcar planning and operations to develop and promote major events around the streetcar geared toward visitors. 


\section{Informant Assessment of Non-Transportation Goal Attainment in Little Rock}

The informants offered a mixed assessment of the River Rail streetcar's attainment of its original goals, with two more favorable and one more pessimistic in their assessments. These assessments tended to rely much more on observations and perceptions than on any formal evaluations. The tourism and visitors expert characterized the streetcar as playing a positive role as an "amenity" of the city and as an attraction itself for visitors because of the "sense of nostalgia" associated with streetcars. He also pointed to economic development that had occurred in the downtowns since the streetcar began operations, although he conceded that it was hard to know if the streetcar was responsible for the development activity. His comments pointed toward the Clinton Presidential Library as a driving factor for development activity in the downtowns more than the streetcar. Nevertheless, his overall assessment of the streetcar was largely favorable.

The transit planner focused his assessment both on the streetcar's economic development effects and its performance as a tourism and visitorship promotion method. With respect to economic development outcomes, he pointed to its "outstanding development effects," as documented in the local study by CATA that found about $\$ 1$ billion in development activity within $1 / 4$ mile of the streetcar line (Central Arkansas Transit Authority 2012). Although he conceded that other factors undoubtedly also were important, he still viewed the streetcar as a critical "catalyst" for development.

With respect to the tourism and visitorship goals, the transit planner interviewee thought the streetcar had been very successful in this regard as well. As evidence, he pointed to the streetcar's strongest ridership months (April and May) being tied to visitors and tourists; the streetcar patronage has a strongly seasonal pattern and is closely tied to major visitor-focused events, including conventions, fairs, school events, and other major public gatherings. He also noted the streetcar's role as an icon of the city that is featured prominently in media coverage of the community.

The regional planner agreed that the streetcar had been embraced as an icon of the city, but he also noted frustrations with the streetcar's performance, including the service's underutilization as a streetcar service as well as one that served the larger community. He expressed frustration with local decisions that undercut the streetcar's ability to attract visitor riders, such as the City of Little Rock's decision to suspend service for "safety" reasons during major public events. The transit planner thought these decisions often were made to increase the supply of on-street parking.

Finally, the regional planner expressed frustrations with the process of trying to move the streetcar beyond the visitor-serving market. He noted that CATA and the metropolitan planning organization have studied extending the streetcar alignment into neighborhoods both north and south of the current alignment, as well as to the airport. He believes the extensions would increase the ridership for the service, but he noted that efforts to pursue funding to permit these extensions to go forward have been unsuccessful. He pointed to CATA's two failed efforts to get a local sales tax passed to support local transit investments and felt that CATA leadership had failed to articulate a vision for how the tax revenue would be used to supplement what they are able to do with their regular, locally-appropriated revenue sources. Nevertheless, he also recognized that CATA has its 
hands full in simply upgrading and maintaining a long-neglected bus system. The most positive assessment he offered was simply that the streetcar had been built.

\section{Streetcar Non-Transportation Goals in Tampa}

Several Tampa interviewees stated that the TECO Line streetcar originated as the proposed "first leg" of a larger LRT system, but they also noted that it soon evolved into a redevelopment and tourism-focused service of much shorter length. According to one business community interviewee, however, the shift in purpose from transit to tourism/ development is not yet completely settled as "groups [in charge of streetcar planning/ operations/finance] are still trying to identify and concur on the main goals for the streetcar; they are not clear and the groups don't understand each other on that aspect; ... some people are still debating if the streetcar should be transit or a cultural piece, or both." This conflict has important consequences for decisionmaking about streetcar planning and operations, given the very different needs and concerns of visitors versus traditional transit riders.

Despite some uncertainty about the streetcar's primary purpose, the interviews indicated that urban redevelopment and tourism historically have driven most decisions made around the streetcar. An economic development interviewee observed that the notion that "urban redevelopment follows transit investment" has been one of the guiding principles of streetcar implementation in Tampa. This idea was based on his understanding of Portland's experience with streetcar implementation and the adjacent development activity that some observers have attributed to the streetcar lines in that city. He believes the Portland experience is replicable in other cities, including Tampa.

Several others pointed to significant development activity along the alignment during the period immediately preceding and shortly after the line's opening, estimated to total about $\$ 1$ billion by one individual. However, most interviewees' overall assessments pointed to a lack of significant development results to date in Tampa's Channelside district. Their assessments pointed particularly to a significant decline in economic activity, including new development, along the alignment since the recession of 2008.

Several interviewees emphasized the role of the streetcar in serving tourists and in providing an identity for Tampa. Many noted that the streetcar has now become a visible image, or icon, of the city. One noted that the streetcar had been featured during national television coverage of major events such as the Super Bowl, while another noted that local residents have embraced the streetcar as a city icon. Whether the idea of creating an icon was in the minds of early streetcar promoters or not, its role as one today is widely perceived among those interviewed for the study. One person even characterized the streetcar as being "transportainment." Clearly, a utilitarian transportation role is not the key role played by the service.

\section{Interviewee Assessment of Non-Transportation Goal Attainment in Tampa}

Many interviewees believe that streetcar implementation in Tampa played a role in encouraging residential and commercial development in the Channelside district and that it has benefited businesses in Ybor City, yet they also recognize that its influence is partial and complementary to other development factors, such as a developer's overall 
economic assessment, building regulations, and local zoning. Special subsides or incentives for promoting development were not used in Tampa, although one interviewee noted that at least one hotel located in the area served by the streetcar did expect the streetcar to be present as a condition for development. Others also pointed to their perception that the streetcar had been a positive amenity in attracting hotel, restaurant, residential, and other developments to the area. It is important to emphasize that all of these assessments derived from observations or perceptions rather than detailed, systematic assessments.

One recurring theme among multiple interviews was the emergence of the streetcar as an icon of the city of Tampa and particularly the Ybor City area. The interviewees noted that the streetcar is featured frequently in news reports and marketing materials prepared for a diversity of purposes. Some perceived this as a positive consequence that contributes to the city's image, has a beneficial effect on Tampa's culture, and possibly encourages visitorship and commercial activity in Ybor City. Another noted that such publicity is "free marketing" that should help encourage streetcar use.

The interviewees also emphasized the role of the economic recession, which had a significant negative impact on Tampa's cruise industry, number of conventions, and commercial activity along the Channelside district. Given Tampa's tourist-oriented service characteristics (i.e., alignment, replica historic vehicles, operating hours, and headways), it also was expected that ridership would decline along with diminished tourism activities. This pattern suggests a greater vulnerability for tourism-oriented streetcar systems to larger-scale economic conditions as compared to streetcar systems that cater to a more diversified ridership market.

\section{Streetcar Transportation Performance}

The authors assessed the transportation performance of the two streetcars by considering ridership, service productivity, cost effectiveness, and other standard performance indicators. They focused on 2012 as the primary year of analysis, but also considered performance trends for certain key indicators over the period from 2005, the first full year in which both streetcars were in operation, until 2012, the most recent year for which data were available at the time of the study.

Table 2 shows the annual ridership and service data for streetcar in both cities from 2005 to 2012 for which data were available from the National Transit Database (accessed via FDOT 2013). Ridership is reported both for unlinked passenger trips, or boardings, and passenger miles; service is reported as service hours and service miles. In 2012, annual ridership in Tampa was nearly three times that of Little Rock. Service hours were virtually identical, and service miles were somewhat higher in Tampa due to slightly higher average streetcar operating speeds (5.4 miles per hour in Tampa vs. 4.4 miles per hour in Little Rock). There are higher levels of population and employment in the immediate vicinity of Tampa's streetcar than in Little Rock (see Table 3), which might explain some of the differences in ridership levels. 
TABLE 2.

Annual Ridership and Service

for Streetcar in Little Rock and Tampa (2005-2012)

\begin{tabular}{|c|c|c|c|c|}
\hline \multirow{2}{*}{ Year } & \multicolumn{2}{|c|}{ Unlinked Passenger Trips (UPT) } & \multicolumn{2}{c|}{ Vehicle Revenue Hours (RH) } \\
\cline { 2 - 5 } & Little Rock & Tampa & Little Rock & Tampa \\
\hline 2005 & 154,745 & 422,536 & 8,072 & 17,580 \\
\hline 2006 & 154,432 & 406,393 & 8,107 & 18,016 \\
\hline 2007 & 154,644 & 431,701 & 11,866 & 17,985 \\
\hline 2008 & 134,204 & 439,555 & 11,992 & 16,090 \\
\hline 2009 & 119,758 & 446,743 & 12,087 & 14,564 \\
\hline 2010 & 107,088 & 399,637 & 11,848 & 13,845 \\
\hline 2011 & 136,380 & 358,737 & 12,535 & 14,423 \\
\hline 2012 & 104,868 & 301,516 & 12,436 & 12,561 \\
\hline Year & Passenger Miles (PM) & Vehicle Revenue Miles (VRM) \\
\hline 2005 & 249,060 & 919,513 & 37,041 & 83,709 \\
\hline 2006 & 248,950 & 838,421 & 38,475 & 86,809 \\
\hline 2007 & 249,052 & 862,224 & 52,256 & 87,147 \\
\hline 2008 & 206,572 & 728,890 & 53,000 & 81,856 \\
\hline 2009 & 183,751 & 776,734 & 53,903 & 74,603 \\
\hline 2010 & 165,718 & 789,244 & 52,702 & 71,395 \\
\hline 2011 & 240,083 & 685,934 & 54,901 & 76,806 \\
\hline 2012 & 162,616 & 523,031 & 54,668 & 67,599 \\
\hline
\end{tabular}

Source: FDOT, 2013, "Florida Transit Information System Access for National Transit Database," http://www.ftis.org, accessed July 26, 2013. 
TABLE 3.

Assessment of Streetcars on Factors Related to Transit Ridership

\begin{tabular}{|c|c|c|c|c|c|}
\hline & Little Rock & Memphis & Portland & Seattle & Tampa \\
\hline \multicolumn{6}{|l|}{ Performance (2012) } \\
\hline Annual ridership (boardings) & 104,868 & $1,491,841$ & $3,664,538$ & 750,866 & 301,516 \\
\hline $\begin{array}{l}\text { Average weekday ridership } \\
\text { (boardings) }\end{array}$ & 400 & 3,240 & 11,729 & 2,560 & 880 \\
\hline $\begin{array}{l}\text { Service productivity (passenger } \\
\text { kilometers per vehicle kilometer) }\end{array}$ & 2.97 & 5.03 & 17.84 & 10.40 & 7.74 \\
\hline $\begin{array}{l}\text { Cost effectiveness (operating } \\
\text { expense per boarding) }\end{array}$ & $\$ 9.61$ & $\$ 2.61$ & $\$ 3.24$ & $\$ 3.73$ & $\$ 5.89$ \\
\hline \multicolumn{6}{|l|}{ Factors } \\
\hline Alignment length (in kilometers) & $\begin{array}{c}5.47 \mathrm{~km} \\
3\end{array}$ & $\begin{array}{c}11.27 \mathrm{~km} \\
4\end{array}$ & $\begin{array}{c}11.83 \mathrm{~km} \\
5\end{array}$ & $\begin{array}{c}4.18 \mathrm{~km} \\
1\end{array}$ & $\begin{array}{c}4.35 \mathrm{~km} \\
2\end{array}$ \\
\hline $\begin{array}{l}\text { Population covered (no. of persons } \\
\text { within } 400 \text { meters of stop) }\end{array}$ & $\begin{array}{c}3,606 \\
1\end{array}$ & $\begin{array}{c}57,518 \\
4\end{array}$ & $\begin{array}{c}117,060 \\
5\end{array}$ & $\begin{array}{c}16,758 \\
3\end{array}$ & $\begin{array}{c}5,651 \\
2\end{array}$ \\
\hline $\begin{array}{l}\text { Employment covered (no. of jobs } \\
\text { within } 400 \text { meters of stop) }\end{array}$ & $\begin{array}{c}1,859 \\
1\end{array}$ & $\begin{array}{c}24,847 \\
4\end{array}$ & $\begin{array}{c}64,899 \\
5\end{array}$ & $\begin{array}{c}10,821 \\
3\end{array}$ & $\begin{array}{c}3,503 \\
2\end{array}$ \\
\hline $\begin{array}{l}\text { Transit connections (no. of } \\
\text { connecting services at stops) }\end{array}$ & $\begin{array}{c}62 \\
1\end{array}$ & $\begin{array}{c}296 \\
4\end{array}$ & $\begin{array}{c}687 \\
5\end{array}$ & $\begin{array}{c}120 \\
3\end{array}$ & $\begin{array}{c}75 \\
2 \\
\end{array}$ \\
\hline $\begin{array}{l}\text { Special generators served* (no. } \\
\text { located within } 400 \text { meters of stop) }\end{array}$ & $\begin{array}{c}66 \\
4\end{array}$ & $\begin{array}{c}11 \\
1\end{array}$ & $\begin{array}{c}40 \\
3\end{array}$ & $\begin{array}{c}140 \\
5\end{array}$ & $\begin{array}{c}22 \\
2\end{array}$ \\
\hline $\begin{array}{l}\text { Fare level (per ride and per day } \\
\text { pass if available) }\end{array}$ & $\begin{array}{c}\text { \$1 ride; } \$ 2 \\
\text { day pass } \\
5\end{array}$ & $\begin{array}{c}\$ 1 \text { ride; } \$ 3.50 \\
\text { day pass } \\
4\end{array}$ & $\begin{array}{c}\$ 1 \text { ride; } \$ 5 \\
\text { day pass } \\
3\end{array}$ & $\begin{array}{c}\$ 2.50 \text { ride; } \\
\$ 5 \text { day pass } \\
1\end{array}$ & $\begin{array}{c}\$ 2.50 \text { ride; } \\
\text { no day pass } \\
2\end{array}$ \\
\hline Transfer policy (availability of free & restrictive & free transfer & $\begin{array}{l}\text { free within } \\
2 \text { hrs }\end{array}$ & $\begin{array}{c}\text { free } \\
\text { transfer }\end{array}$ & $\begin{array}{l}\text { no free } \\
\text { transfer }\end{array}$ \\
\hline & 2 & 5 & 3 & 5 & 1 \\
\hline $\begin{array}{l}\text { Headways (average weekday peak } \\
\text { period) }\end{array}$ & $\begin{array}{c}25 \mathrm{~min} \\
1 \\
\end{array}$ & $\begin{array}{c}10 \min \\
5 \\
\end{array}$ & $\begin{array}{c}14-17 \text { min } \\
3 \\
\end{array}$ & $\begin{array}{c}10 \min \\
5\end{array}$ & $\begin{array}{c}20 \min \\
2 \\
\end{array}$ \\
\hline Service hours (average weekday) & $\begin{array}{c}14 \mathrm{hrs} \\
2\end{array}$ & $\begin{array}{c}17 \mathrm{hrs} \\
4\end{array}$ & $\begin{array}{c}18 \mathrm{hrs} \\
5 \\
\end{array}$ & $\begin{array}{c}15 \mathrm{hrs} \\
3\end{array}$ & $\begin{array}{c}10 \mathrm{hrs} \\
1 \\
\end{array}$ \\
\hline $\begin{array}{l}\text { Day-long service (serves both peak } \\
\text { periods) }\end{array}$ & $\begin{array}{c}\text { no } \\
0\end{array}$ & $\begin{array}{c}\text { yes } \\
1\end{array}$ & $\begin{array}{c}\text { yes } \\
1\end{array}$ & $\begin{array}{c}\text { yes } \\
1\end{array}$ & $\begin{array}{c}\text { no } \\
0\end{array}$ \\
\hline $\begin{array}{l}\text { Seasonality (monthly ridership } \\
\text { variation by time of year) }\end{array}$ & $\begin{array}{c}\text { yes } \\
0\end{array}$ & $\begin{array}{c}\text { yes } \\
0\end{array}$ & $\begin{array}{c}\text { no } \\
1\end{array}$ & $\begin{array}{c}\text { no } \\
1\end{array}$ & $\begin{array}{c}\text { yes } \\
0\end{array}$ \\
\hline TOTAL & 20 & 36 & 39 & 31 & 16 \\
\hline
\end{tabular}

*Special generators include hotels, convention centers, museums, university campuses, and other major activity centers.

Between 2005 and 2012, streetcar ridership in both cities fell between 30 and 40 percent. Streetcar service levels increased by about 50 percent in Little Rock and declined by about 20 percent in Tampa. In Tampa, part of the decline in streetcar ridership is no doubt attributable to the decline in service, although this is clearly not the case for Little Rock. The decline in streetcar ridership in both cities stands in stark contrast to bus ridership trends over the same time period. In Little Rock, bus ridership increased about one-third between 2005 and 2012, and bus service increased by only about 3 percent. In Tampa, bus ridership increased about 40 percent between 2005 and 2012, as bus service increased by about 10 percent (FDOT 2013). 
Streetcar ridership in both cities is highly seasonal (see Figure 5). This stands in stark contrast with streetcar service, bus ridership, and bus service levels, none of which exhibit seasonal patterns (Federal Transit Administration 2013). The seasonality of streetcar ridership can be seen clearly in the monthly ridership data presented in the figure. Little Rock's busiest ridership months are between March and July; ridership in the busiest month (May) is more than three times that of several other months of the year, thus indicating the strong visitor orientation of the service. Tampa's busiest months are from December through April; ridership peaks in March, when it reaches levels about twice that of the lowest ridership months (August and September). Tampa's busiest riding months correspond with the peak of the tourism season in the city. In 2012, average weekday streetcar ridership was about 400 boardings per day in Little Rock and 880 boardings per day in Tampa (HART 2012).

FIGURE 5.

Monthly boardings by streetcar in Little Rock and Tampa (2012)

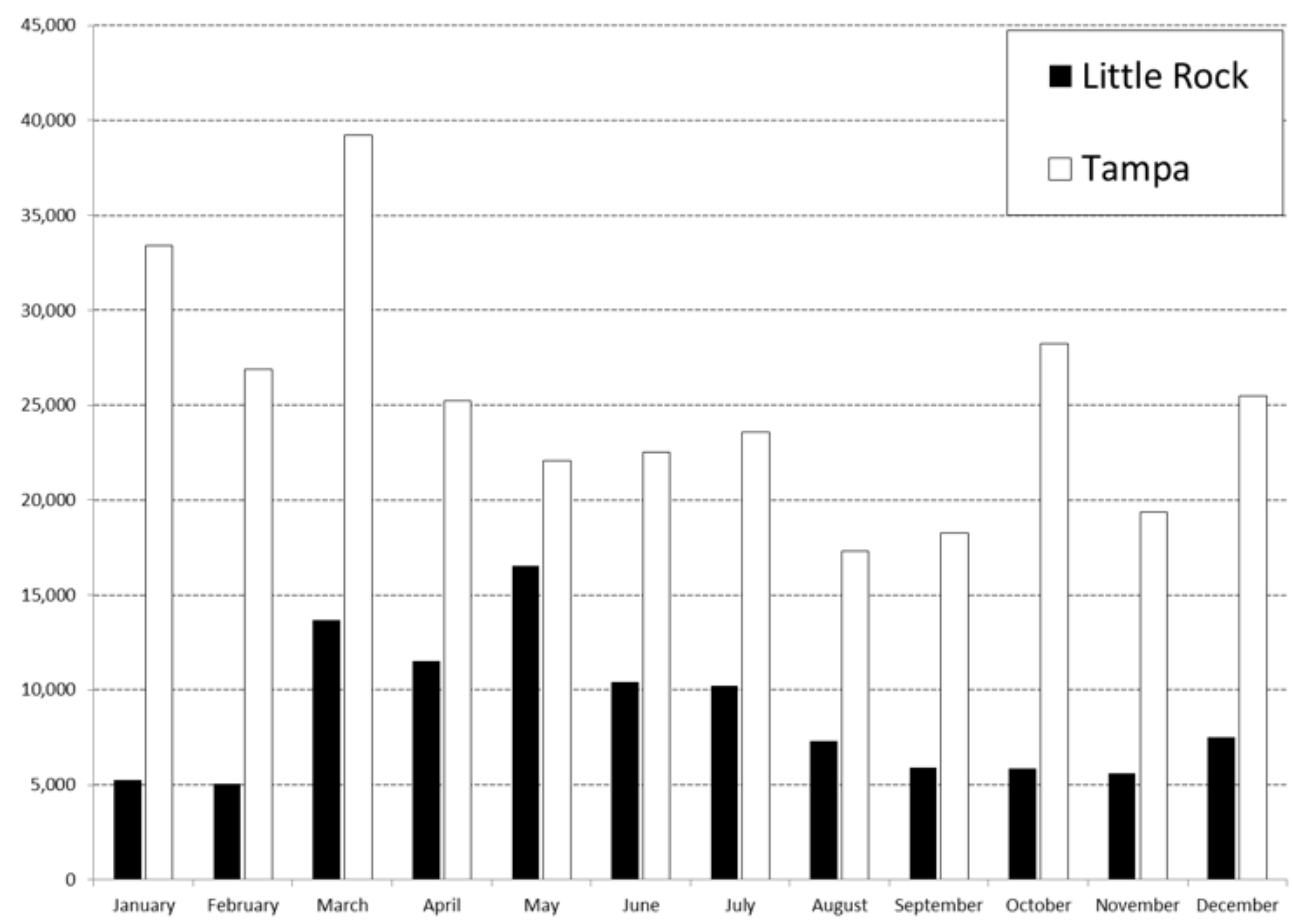

In recent years, both cities experienced deteriorating streetcar service performance. Between 2005 and 2012, service productivity (passenger kilometers per vehicle kilometer) declined 56 percent in Little Rock (from 6.73 to 2.97) and 30 percent in Tampa (from 10.98 to 7.74) (FDOT 2013). Operating expense per passenger trip increased significantly over the same time period in Little Rock (131\% increase from $\$ 4.16$ to $\$ 9.61$ per trip, in 2012 dollars) and in Tampa (21\% increase from \$4.94 to \$5.89 per trip, in 2012 dollars) (FDOT 2013).

Streetcar service has become less productive and less cost effective in both cities. In 2012, streetcar service productivity was below that of the average bus route in both cities (2.97 vs. 6.84 in Little Rock; 7.74 vs. 9.76 in Tampa); streetcar operating costs per passenger trip exceeded those for bus in both cities (\$9.61 vs. $\$ 4.45$ in Little Rock; $\$ 5.89$ vs. $\$ 3.84$ in Tampa) (FDOT 2013). In 2012, Little Rock and Tampa ranked last and next to last, respectively, among the modern-era streetcar cities on ridership and cost effectiveness, 
and ranked among the bottom three streetcar cities in service productivity (see Table 3 ) (FDOT 2013; Ramos et al. 2014). The streetcars in these two cities are poor transit performers.

The authors assessed the two cities against three streetcar peers (Portland, Memphis, and Seattle) on several different factors that the transit literature has linked to ridership (see Table 3) (FDOT 2013; Ramos et al. 2014). On each factor, cities receive a higher score for better performance and a lower score for worse performance. The totals for all scores are shown at the bottom of Table 3. Not surprisingly perhaps, Little Rock and Tampa fares the worst when assessed over the entire set of factors; they are particularly noteworthy for the low population and employment levels in the areas near the streetcar lines, the low number of connections at streetcar stops to other transit services, and the relatively infrequent service and short hours of service. By contrast, Portland emerges as the standout performer on this assessment; it is also known for its high ridership and productive service among modern-era streetcar cities (Ramos et al. 2014).

In short, the Little Rock and Tampa streetcars do not appear to be located in areas with strong transit riding potential, and planners have not made decisions in a way that maximizes the streetcars' utility for serving transit riders by making the service easy and convenient to use. This makes the streetcars even more dependent on visitors and tourists and on the generation of economic development to generate potential ridership. The ridership data clearly indicate that they have not been particularly successful in doing so to date, and the lack of any careful assessment or documentation of economic development or tourism promotion effects also raises serious questions about their actual performance in those areas.

\section{Discussion and Lessons}

Little Rock's River Rail and Tampa's TECO Line streetcars stand out as being among the poorest transportation performers among the modern-era U.S. streetcar cities and pale in comparison to Portland, whose streetcar lines carried about 12,000 riders per day during the same time that Little Rock and Tampa carried 400 and 880 riders per day, respectively. The two streetcars have much lower service productivity and offer much less cost-effective service than the average local bus in their communities. Some of these poor transportation results are due to external factors, including the health of the local economy, but conscious policy decisions have played a role as well, particularly the selection of alignment length and location and the decision (either explicitly or implicitly) to focus on serving tourist riders as opposed to a wider array of transit riders. Because this particular rider market is more sensitive to the overall health of the economy, tourism-oriented modern-era streetcars are more vulnerable to economic downturns and ridership decline, and this has occurred in both cities.

Although the key informant interviews emphasized the streetcars' use as tools to serve tourism promotion and economic development, as opposed to their utility as transit services, their performance in these areas is not strongly supported by technical studies. Save for a single study commissioned by CATA that relied on a very simple GIS analysis of economic development activity around the River Rail lines, anecdotal observations and 
individuals perceptions are all that can be found in support of the purported economic development effects associated with the streetcar investments. Still, available data do indicate that they are carrying some tourists, at least in part due to their roles as local amenities or novelty attractions that are being promoted as part of the city's image; it is unlikely that bus transit could play such a role for this rider market. However, these tourist riders are being carried at a fairly high cost per ride and after making significant capital investment in the streetcar. Thus, the net benefit of the investment is an open question that would benefit from more careful analysis (Brown et al. 2014).

What should other cities take away from the experiences of these two cities? First, the authors suggest that streetcars need to carry riders to deliver benefits to the community, whether in the form of economic development, tourism promotion, or transportation service. The streetcars in Tampa and Little Rock carry few riders, and the ridership trends are in a declining direction. Policy and planning decisions should work toward making transit service more attractive to riders through the provision of convenient schedules and attractive fares. If the focus is on the visitor rider market, using the streetcar as a key transportation piece of events catering to visitors would seem a logical strategy, and one not always followed in Little Rock in particular. If the focus is on serving a broader array of riders, paying attention to connections to other transit services and implementing attractive transfer policies to encourage rider use of connecting services; neither of these objectives appear to be priorities in these two cities. On the other hand, planners in Portland have paid attention to these concerns by providing the frequent service and network connections that transit riders value and that planners in Little Rock and Tampa have ignored (Brown et al. 2014).

Second, decisionmakers should understand the uniqueness of their community and not simply assume that the experiences of other communities can be easily replicated. Decisionmakers in Little Rock and Tampa were inspired by the example of Portland and thought they could easily replicate what they saw as the outcomes of Portland's investment in streetcar services. They did so despite really understanding that Portland's experience was the result of a combination of factors, of which the presence of a streetcar line was merely one. Little Rock and Tampa lacked many of the other attributes that Portland possesses that encourage greater transit ridership by residents of that community, such as higher densities of population and employment, a strong local real estate market, a history of coordinating land use and transportation policies, and a transit system known for operating frequent, well-coordinated, convenient services. The decisionmakers in Tampa simply saw the economic development activity and attractive mixed-use urban environments around the Portland streetcar line and assumed that building their own streetcars would lead to the same results.

This has not been the case. In Little Rock, it appears that recent investments near the streetcar alignment can be attributed to several factors. As mentioned by one of the interviewees, the opening of the Clinton Library and the Farmer's Market have exerted influence on recent developments downtown, with the streetcar serving as an additional amenity (Brown et al. 2014). 
Planners and policymakers in other cities should think very carefully before making similar decisions for their communities, as this cautionary tale could also apply to other capital-intensive transit projects currently undergoing planning or implementation efforts. Transit investments can serve multiple transportation and non-transportation objectives, yet the authors suggest that their achievement depends primarily on their ability to move people conveniently from where they are to where they wish to be. For this to happen, planners and decisionmakers need to pay attention to streetcar transit service, connectivity to other transit systems in the region, regional economy trends, real estate trends, land-use characteristics, and development incentives. These need to be considered in the early planning stages and in ongoing streetcar operation decisions while catering to a wider set of users beyond tourists and visitors.

\section{Acknowledgments}

The authors thank the 10 individuals who participated in the key informant interviews for this study for contributing their time and insights. The authors greatly appreciate the insights provided by a Tampa-based transportation researcher who clarified several points made in the paper. The authors also thank the staffs of CATA and HART for their assistance with images and data. Finally, the authors thank the Mineta Transportation Institute at San Jose State University for its generous financial support of this work.

\section{References}

Brown, Jeffrey, Hilary Nixon, and Luis Enrique Ramos. 2014. The purpose, function, and performance of streetcar transit in the modern U.S. city: A multiple case study investigation. San Jose, CA: Mineta Transportation Institute.

Central Arkansas Transit Authority (CATA). 2012. River Rail economic enhancement study - Development along the River Rail Streetcar System 2000-2012.

Central Arkansas Transit Authority (CATA). 2014. GIS Shapefiles for CATA bus routes, River Rail streetcar line, and River Rail streetcar stops.

Federal Transit Administration. National Transit Database: Monthly module adjusted data release for May 2013. http://www.ntdprogram.gov/ntdprogram/pubs/MonthlyData/May_2013_ Adjusted_Database.xls. Accessed July 29, 2013.

Florida Department of Transportation (FDOT). Florida Transit Information System Access for National Transit Database. http://www.ftis.org. Accessed July 26, 2013.

Golem, Ron, and Janet Smith-Heimer. 2010. Relationships between streetcars and the built environment: A synthesis of transit practice. Transit Cooperative Research Program Synthesis 86. Washington, DC: Transportation Research Board.

Hillsborough Area Regional Transit (HART). 2012. Average weekday boardings by station, 2012. Hillsborough Area Regional Transit (HART). Transit network shapefiles, 2012. 
http://www.gohart.org/about/data_download/data_download.html. Accessed October 2, 2012.

Hovee, Edward, and Richard Gustafson. 2012. Streetcar-development linkage: The Portland Streetcar loop. Conference paper.

Ramos, Luis Enrique, Jeffrey Brown, and Hilary Nixon. 2014. The transit performance of modern-era streetcars: A consideration of five U.S. cities. Paper presented at the 94th Annual Meeting of the Transportation Research Board in Washington, DC, January 11-15, 2015.

\section{About the Authors}

LUIS EnRIQUe Ramos, M.Arch., M.P. (ler12@my.fsu.edu) is a doctoral student in the Department of Urban and Regional Planning at Florida State University. His research interests include the evolution of inner-ring suburbs, multidisciplinary social-ecological urban research, sustainable transportation, determinants of transit ridership, and transportation/ land-use interactions. He holds bachelor's and master's degrees in Architecture from Tulane University, New Orleans, and a master's degree in Urban and Regional Planning from the University of Puerto Rico Graduate School of Planning.

Dr. JefFrey BROWN (jrbrown3@fsu.edu) is Associate Professor, Department Chair, and Master's Program Director in the Department of Urban and Regional Planning at Florida State University. His research interests include transportation finance, transportation history, and public transportation policy and planning. He holds a B.A. in Geography, an M.A. in Urban Planning, and a Ph.D. in Urban Planning from the University of California, Los Angeles.

Dr. Hilary Nixon (hilary.nixon@sjsu.edu) is an Associate Professor of Urban and Regional Planning at San José State University. Her research and teaching interests in environmental planning and policy focus on the relationship between environmental attitudes and behavior, particularly with respect to waste management and linkages between transportation and the environment. She holds a B.A. in Environmental Management from the University of Rochester and a Ph.D. in Planning, Policy, and Design from the University of California, Irvine. 